\title{
Assaults on Transport Workers
}

\author{
David Sharp
}

Defining what a city is and where its boundaries lie can be difficult. In the UK, one test used to be the possession of a cathedral, a criterion that produced odd results. Today, city status is awarded on other grounds. All the same, it was surprising when media coverage of a report from the University of Sheffield, published in the June of last year, ${ }^{1}$ left the impression that everyone below a diagonal line running roughly from the Severn estuary in the west to the Wash on the east coast of England was now living in "Greater London". Happily, this is neither a geographical statement nor an architectural one but a socioeconomic. Better-paid jobs in the southeast continue to act as a magnet. There have been attempts to reverse this migration. Government offices have been decentralized-for example, my income tax return now goes to Edinburgh instead of Cardiff but I have never worked or lived in Scotland or Wales. Also, the northern city of Leeds is fast becoming a competitor to London in the provision of legal expertise. However, these movements appear to have had little impact. Professor Daniel Dorling, coauthor of the Sheffield report, is quoted as saying that to the north and west of the metropolis of "Greater London" lies the " archipelago of the provinces' - city islands that appear to be slowly sinking demographically, socially and economically."2 How such a social decline would manifest itself is anybody's guess.

If London (which, as the report notes, does itself have pockets of socioeconomic deprivation) is by and large the exception to a gloomy future for British cities, it does not seem to be bucking the trend in various forms of antisocial behavior. National figures issued last July ${ }^{3}$ managed to confuse everyone, with violent crime going up by $12 \%$, according to police records whereas the British Crime Survey, based on interviews, suggested a 3\% fall. Perhaps, we are on firmer ground with assaults on transport staff (mass transit workers), an employment group focused on in this issue of the Journal of Urban Health. No one is disputing the rise in assaults on such workers. Calling for "zero tolerance" a year ago, the Transport Salaried Staffs' Association noted an 18\% rise in assaults on rail staff between 2002 and 2003 and in the recording year 2003-2004, the British Transport Police registered 820 assaults on tube workers.

Abuse need not be physical. Much of it is verbal and insults can be hurtful. Instances of staff being spat at have prompted one city-based transport authority to issue DNA kits so that culprits can be identified. The abuse may not even be intended. Suicide on rail tracks causes huge stress to train drivers and such tragedies prompt the offer of psychological counseling. According to the Rail Safety and Standards Board, ${ }^{4}$ there are 50 suicides a year on average on London Underground and 179 on ordinary rail tracks (2003 figure).

Alcohol abuse is not unique to cities but the harmful and degrading consequences of binge drinking, especially by the young and at weekends, are often seen in urban settings. ${ }^{5}$ Transport workers are sometimes in the firing line on these occasions, and the impact on these employees may be forgotten in the understandable 
emphasis on the consequences to health and the economy-17 million working days lost every year, according to the Prime Minister's Strategy Unit, with an annual alcohol-related National Health Service bill of $£ 1.7$ billion. ${ }^{5}$

The first services on London's Underground began in 1863 with coal-fired engines, a working atmosphere difficult to imagine. The pollution may have been largely removed and much of the expanded Underground is not even subterranean, so less claustrophobic. Today, transport workers face new hazards that stem from the public's behavior. However a city is defined, and whether it is sinking or blooming, a mass transit system, with buses, railways, undergrounds, and, in the UK, resurrected tramways is essential. Assaults, verbal and physical, and alcohol-related incidents have become part of the daily life of many public-service workers, including drivers, conductors, and ticket staff in public transport.

\section{REFERENCES}

1. Dorling D, Thomas B. People and Places, A 2001 Census Atlas of the UK. Bristol: Policy Press; 2004.

2. University of Sheffield Media Centre. New study reveals widening north-south divide. Available at: http://www.shef.ac.uk/mediacentre/2004/217.html. Accessed July 19, 2004.

3. Crime in England and Wales. Available at: http://www.crimereduction.gov.uk/ sta_index.htm\#Crime. Accessed July 25, 2004.

4. Rail Safety and Standards Board. Suicides on the railway. Available at: http:// www.rssb.co.uk/natini_suicides.asp. Accessed February 2, 2005.

5. Prime Minister's Strategy Unit. Alcohol Harm Reduction Strategy for England. London: Cabinet Office; 2004. 